\title{
Seed Treatment Effects on Maize Seedlings Coinfected with Fusarium spp. and Pratylenchus penetrans
}

\author{
M. P. da Silva, G. L. Tylka, and G. P. Munkvold, Department of Plant Pathology and Microbiology, Iowa State University, Ames 50011
}

\begin{abstract}
da Silva, M. P., Tylka, G. L., and Munkvold, G. P. 2016. Seed treatment effects on maize seedlings coinfected with Fusarium spp. and Pratylenchus penetrans. Plant Dis. 100:431-437.

Seedling diseases of maize are caused by a complex of organisms, including fungi in the genus Fusarium. Root-lesion nematodes (Pratylenchus spp.) are common in fields where maize is grown, and they are known to interact with Fusarium spp. in several crops. The objectives of this study were to assess the impacts of seed treatment combinations on maize seedlings coinfected with Pratylenchus penetrans and two Fusarium spp. that cause seedling disease symptoms (Fusarium graminearum and $F$. verticillioides) and to determine whether there were interactions between $P$. penetrans and the Fusarium spp. Growth-chamber experiments were conducted with fungicideor nematicide-treated or untreated maize seed planted in a sand-soil mixture infested with inoculum of either $F$. graminearum or $F$. verticillioides. A suspension of 4,000 P. penetrans (mixed stages) was added to the pots at the time of planting. After 30 days, shoot length and fresh and dry shoot and root

weights were determined. Total root length and fine root length, root volume, numbers of root tips and forks, and root surface area were measured through analysis of digital images of the root systems. After 42 days, $P$. penetrans nematodes were extracted and quantified from roots and soil. There were significant effects of the treatments on root health with interactions between $F$ usarium spp. and $P$. penetrans. F. graminearum caused the greatest reductions in root and shoot growth, and interactions with $P$. penetrans were more evident for $F$. verticillioides than for $F$. graminearum. Image analysis of root system architecture showed that seed treatment significantly improved root system characteristics. Seed treatments containing the nematicide abamectin in combination with fungicides reduced root infection by $P$. penetrans and provided the healthiest root system when under attack by the FusariumPratylenchus complex.
\end{abstract}

Pratylenchus penetrans (Cobb) Filipjev \& Schuurmans Stekhoven (root-lesion nematode) is one of the most common Pratylenchus spp., with a wide range of hosts and a cosmopolitan distribution throughout temperate regions (Corbett 1973; Loof 1991; Mai et al. 1977). This nematode is one of the most common species found on maize (Zea mays L.) in the United States (Norton 1984) and parts of Canada (Potter and Townshend 1973). The mechanism of pathogenesis of $P$. penetrans includes direct feeding damage to roots and interactions with other organisms in disease complexes, such as those involving fungi (Endo 1975). P. penetrans feeding can result in predisposition to other pathogens by wounding of the roots. Nematode-fungus interactions can result in additive or synergistic effects on disease development and impact (Back et al. 2002).

Maize seed and seedlings are susceptible to infection by several Fusarium spp.; Fusarium graminearum Schwabe and $F$. verticillioides (Sacc.) Nirenberg are among the most important species that can cause seedling diseases (Munkvold and O'Mara 2002). The symptoms caused by these pathogens are very similar: failure to emerge, wilting, chlorosis or yellowing, root rot and poor root development, slow growth and stunting, and postemergence damping-off. Seedling diseases cause losses by reducing plant populations and delaying the growth and development of surviving plants. In severe cases, seedling diseases can reduce plant population to the level that replanting is necessary (Robertson and Munkvold 2009; Stack 2000; Vincelli 2008).

The first report of an interaction between a plant-parasitic nematode and a soilborne plant-pathogenic fungus was published in 1892 (Atkinson 1892); Fusarium wilt of cotton (caused by F. oxysporum f. sp. vasinfectum) was more severe in soil coinfested with Meloidogyne spp. Further evidence for the interaction between Fusarium spp. and Meloidogyne spp. in cotton was later provided during field experiments, in which soil was treated with ethylene dibromide or 1,3 dichloropropene (Newson and Martin 1953; Smith 1948). It also has been shown that Pratylenchus spp.

Corresponding author: G. P. Munkvold. munkvold@iastate.edu

Accepted for publication 11 August 2015.

http://dx.doi.org/10.1094/PDIS-03-15-0364-RE

(C) 2016 The American Phytopathological Society appear to be the dominant nematodes involved in synergistic interactions with Verticillium wilt fungi (Burpee and Bloom 1978; Huan et al. 1988; Martin et al. 1982; Mountain and McKeen 1962; Olthof and Reynes 1969; Rowe and Powelson 2002; Rowe et al. 1985).

Soil nematicides can be used to control plant-parasitic nematodes in maize, significantly reducing soil population densities. For example, applications of 1,3-D and carbofuran combined resulted in good control of $P$. hexincisus (Norton and Hinz 1976). However, use of soilapplied nematicides is often cost prohibitive, and increasing concerns about the environment, food safety, and public health has resulted in the gradual phasing out of many soil-applied nematicides (McKenry et al. 1994; United Nations Environment Programme 1992), leading to a need for alternative management tactics such as seed treatment.

Nematicides used as seed treatments are more cost-efficient and environmentally friendly tools for nematode management compared with soil applications of nematicides. For example, with the advent of products such as Avicta (abamectin; Syngenta Crop Protection, Inc.) N-Hibit (harpin protein; Plant Health Care, Inc.), Aeris (thiodicarb; Bayer Crop Science, Inc.), and Votivo bionematicide (Bacillus firmus; Bayer Crop Science, Inc.) as seed treatments used in cotton, soybean, and maize, more options are available to control plant-parasitic nematodes using less chemical input than was necessary with soil applications of nematicides. Abamectin proved to be very effective in reducing early infection by Pratylenchus spp. and Heterodera schachtii in maize and sugar beet roots, respectively, and also gall formation by Meloidogyne spp. in cotton (Cabrera et al. 2009). In fact, this study showed that abamectin at $1.0 \mathrm{mg}$ of active ingredient (a.i.) seed ${ }^{-1}$ reduced penetration of maize roots by $P$. zeae by more than $80 \%$ during the first 14 days after nematodes were added to the soil. For this reason, assessment of the effects of these products on nematode-fungus interactions in maize is needed. Nematicidal and nematode-protectant seed treatments also provide new research tools to facilitate better understanding of the mechanisms of nematode-fungus interactions. The objectives of this study were to (i) assess the impact of seed treatment combinations (including abamectin-fungicide combinations) on maize seedlings coinfected with $P$. penetrans and $F$. graminearum or $F$. verticillioides and (ii) determine whether there were interactions between $P$. penetrans and the Fusarium spp., especially with respect to effects on root system growth and development. 


\section{Materials and Methods}

Experimental design. Separate experiments were conducted with either $F$. verticillioides or $F$. graminearum. Each experiment was conducted twice in a growth chamber at Iowa State University, Ames. A full factorial experimental design was used. Experimental factors were seed treatment (eight treatments), $P$. penetrans treatment (infested or not), and fungal treatment (infested or not). Seed of maize NK Brand hybrid N40T-GT (Syngenta Seeds) was commercially treated by the manufacturer with seven different combinations of active ingredients, and a nontreated control was included. All treatments included a base combination of the fungicides fludioxonil, mefenoxam, and azoxystrobin (FMA), and some treatments included an additional fungicide (thiabendazole), insecticide (thiamethoxam), or nematicide (abamectin) (Table 1). Seed treatments were manufacturer (Syngenta Crop Protection) formulations applied at the recommended rates for commercial use. The 32 treatment combinations were arranged in a growth chamber as a randomized complete block design with six replicates. Plant were grown in 164-ml cones (Ray Leach Cone-tainers, model SC10; Stuewe and Sons, Inc.). Each cone was an experimental unit. Plants were maintained in a growth chamber under light supplied by cool-white fluorescent and incandescent lamps with a photoperiod of $14 \mathrm{~h}$. Relative humidity was maintained at $99 \%$ and temperature was $22 \pm 0.1^{\circ} \mathrm{C}$. The plants were watered once a day using a watering can ( $20 \mathrm{ml} /$ plant) and fertilized once a week, using Peters Excell water-soluble fertilizer (15-5-15; Everris U.S., Inc.). A small piece of paper towel in the bottom of each cone partially reduced drainage.

Fungal and nematode infestation. Fusarium isolates ISUA66A ( $F$. graminearum) and ISU93048 ( $F$. verticillioides), isolated from kernels of maize grown in Iowa, were used in the experiments. Inoculum of Fusarium isolates was prepared following the procedure described by Munkvold and O'Mara (2002), modified from that of Desjardins et al. (1995). A mixture of sand (1,900 ml), corn meal $(380 \mathrm{ml})$, and water $(110 \mathrm{ml})$ was autoclaved in bags for $1 \mathrm{~h}$ at $121^{\circ} \mathrm{C}$ on two consecutive days. Spore suspensions $\left(10^{6}\right.$ conidia ml $\left.{ }^{-1}\right)$ of the Fusarium isolates were prepared from cultures on carnation leaf agar (Leslie and Summerell 2006). A spore suspension (2 ml) of one of the Fusarium isolates was injected into each bag. The bags were then incubated in the dark at ambient temperature $\left(20\right.$ to $\left.24^{\circ} \mathrm{C}\right)$ for 6 days, with mixing every day. Autoclaved sand-soil (1 part soil to 2 parts sand) was mixed with the fungal inoculum. The proportion was $30 \%$ of inoculum and $70 \%$ by volume of the sand-soil mixture. Cones were filled with the mixture and one maize seed was placed in each cone. $P$. penetrans, provided by Dr. A. E. MacGuidwin (University of Wisconsin, Madison), was cultured monoxenically (Layne and MacGuidwin 1994) on excised maize roots in Gamborg's B-5 medium with vitamins and without cytokinins or auxin (Gamborg et al. 1976). Agar surfaces of 3-month-old cultures were rinsed with sterile distilled water to collect nematodes (Layne and MacGuidwin 1994). The nematode inoculum was prepared in a water suspension in a total volume of $50 \mathrm{ml}$, which was then diluted to achieve a density of 2,000 nematodes $\mathrm{ml}^{-1}$ determined by counting using a nematode counting slide under a dissecting microscope. Nematodes were added to the cones by injecting a 2-ml nematode suspension (equivalent to
4,000 nematodes) to a depth of approximately $2.5 \mathrm{~cm}$ using a microliter pipette at the time of planting (Saeed et al. 1999).

Data collection and analysis. Seedling emergence was recorded daily from the day the first plant emerged until 30 days after planting. Four replicates were harvested 30 days after planting. Plants were removed from the cones, soil adhering to the roots was shaken free, and the roots were washed thoroughly. Shoot lengths (flag leaf) and fresh shoot and root weights were measured. Shoots and roots were oven dried at $110^{\circ} \mathrm{C}$ for $24 \mathrm{~h}$ and weighed.

To assess root morphology for each treatment, roots were scanned and images analyzed using the software WinRhizo 2008a (Regent Instruments Inc.). Intact washed roots were spread in a transparent tray in order to avoid overlapping during the scanning process. Image recording was performed at a resolution of 600 dots per inch using a 24-bit color mode, and images were saved as TIFF files. All other scanner settings (such as dust removal) were turned off. A Dell Precision T3500 desktop computer (Dell Inc.) was used to drive the Epson Perfection V700 Photo-Dual Lens System scanner (Seiko Epson Corp.). Root morphology was examined and the following measurements were recorded: total root length (centimeters), total surface area (square centimeters), total volume (cubic centimeters), number of tips, number of forks, and length (centimeters) of fine roots $(<0.5 \mathrm{~mm}$ in diameter).

Two replicates per treatment were harvested after 6 weeks in order to extract $P$. penetrans from soil and roots. A $100 \mathrm{~cm}^{3}$ soil sample was collected after the soil was removed from the cones, thoroughly mixed, and $P$. penetrans were extracted using the centrifugal flotation technique (Jenkins 1964). Roots were cut into small pieces $(1 \mathrm{~cm})$ long, mixed and incubated in Baermann funnels for 2 days (De Waele and Elsen 2002). After nematodes were collected, the roots were dried at $100^{\circ} \mathrm{C}$ for 2 days and weighed. The number of $P$. penetrans (juveniles and adults) that had emerged from the roots was counted using an inverted microscope and a nematode-counting slide. The total number of nematodes present per pot was calculated based on soil volume and root weight. Also, the number of $P$. penetrans nematodes per gram of dry root weight was determined.

Data were analyzed by analysis of variance (ANOVA) for a completely randomized block design (SAS Inc.). Least significant differences $(\alpha \leq 0.05)$ for comparing treatment means also were calculated according to the GLM procedure of SAS. In order to meet ANOVA assumptions of normality and equal variances, ANOVA were performed on transformed $\left(\log _{10}\right)$ data, except for nematode population data, which were not transformed. Analysis of all main effects and interactions was conducted using all treatment combinations. Because of significant seed treatment-pathogen infestation interactions, seed treatment effects also were tested for treatments infested with Fusarium spp. and $P$. penetrans only, excluding the noninfested treatment combinations. Data from the two runs of each experiment were combined for analysis.

\section{Results}

F. graminearum experiments. Fungal infestation strongly affected all the variables measured, whereas nematode infestation affected only

Table 1. Seed treatments used in the experiments ${ }^{\mathrm{z}}$

\begin{tabular}{|c|c|c|c|c|c|}
\hline Treatment & Active ingredients & Chemical group & Formulation (\%) & Brand name & Rate \\
\hline \multirow[t]{3}{*}{1} & Fludioxonil & Phenylpyrrole & 40.3 & Maxim & $2.5 \mathrm{~g} / 100 \mathrm{~kg}$ \\
\hline & Mefenoxam & Phenylamide & 1.1 & Apron XL & $2 \mathrm{~g} / 100 \mathrm{~kg}$ \\
\hline & Azoxystrobin & Strobilurin & 9.6 & Dynasty & $1 \mathrm{~g} / 100 \mathrm{~kg}$ \\
\hline 2 & FMA + thiabendazole & Benzimidazole & 42.3 & MaximQuattro & $20 \mathrm{~g} / 100 \mathrm{~kg}$ \\
\hline 3 & FMA + thiamethoxam & Neonicotinoid & 47.6 & Cruiser & $0.25 \mathrm{mg} / \mathrm{seed}$ \\
\hline 4 & FMA + thiamethoxam + thiabendazole & $\ldots$ & 47.6 & CruiserMaxx & $\ldots$ \\
\hline 5 & FMA + abamectin & Avermectin & 46.3 & Avicta & $0.25 \mathrm{mg} / \mathrm{seed}$ \\
\hline 6 & FMA + abamectin + thiabendazole & $\ldots$ & 12.4 & $\ldots$ & $\ldots$ \\
\hline 7 & $\begin{array}{l}\text { FMA + abamectin }+ \text { thiamethoxam }+ \\
\text { thiabendazole }\end{array}$ & $\ldots$ & 12.4 & $\cdots$ & $\cdots$ \\
\hline 8 & Untreated & $\ldots$ & 0 & $\ldots$ & $\ldots$ \\
\hline
\end{tabular}

${ }^{\mathrm{z}}$ Treatment 1 is the commercial standard and consists of fludioxonil + mefenoxam + azoxystrobin (FMA), and treatments 2 through 7 include FMA at the same rates as treatment 1 . 
shoot dry and root dry weights as a main effect. Also, there were significant interactions between $F$. graminearum and $P$. penetrans affecting root dry weights and fine roots (Table 2 ). Seed treatment significantly affected all the root variables except weight but did not have a main effect on shoot variables. There were strong interactions between seed treatment and fungal infestation effects for all the variables measured, reflecting the fact that the effects of most seed treatments occurred only when the fungus was present. There were significant interactions between seed treatment and nematode infestation affecting shoot length, shoot fresh weight, and root fresh weight. There were no significant three-way interactions between seed treatment, fungal infestation, and nematode infestation for any of the measured variables. There were significant effects of seed treatment on the numbers of nematodes extracted from soil $(P<0.0001)$ and from the roots $(P=0.004)$; treatments including the nematicide abamectin were the only ones differing significantly from the untreated control (Table 3 ).

Seed treatments (which all contained fungicides) were very effective for improving seedling health in $F$. graminearum-infested treatments; all seed treatments significantly improved all variables compared with the untreated control, except for fine root length. Values for measurements of seedling morphology were often increased more than twofold by seed treatments in comparison with the untreated control. Treatments 6 (FMA + abamectin + thiabendazole) and 7 (FMA + abamectin + thiamethoxam + thiabendazole) often resulted in the highest means but, in many cases, the means were not significantly different from the other seed treatment combinations (Table 4). In $P$. penetransinfested treatments, there were significant seed treatment effects for all variables except fine root length but not all the seed treatments differed from the untreated control (Table 4); treatments including abamectin most often differed from the control. Treatment 6 (FMA + abamectin + thiabendazole) was significantly different from the untreated control for all treatments except fine root length. Seed treatments did not affect any of the measured variables in the noninfested control treatments. $P$. penetrans was not detected in noninfested controls.

$\boldsymbol{F}$. verticillioides experiments. Effects of this fungus were weaker than those of $F$. graminearum. As a main effect, $F$. verticillioides infestation significantly affected root length, root volume, number of tips, number of forks, root surface area, and number of fine roots. At the same time, nematode infestation significantly affected root length, number of tips, number of forks, root surface area, number of fine roots, and root volume (Table 2). There were significant interactions between seed treatment and fungal infestation for all the variables except dry weights and shoot length. There were significant interactions between seed treatment and nematode infestation affecting shoot length and fresh weight, root length, forks, and fine roots. Compared with the $F$. graminearum experiments, there were many more significant interactions between $F$. verticillioides infestation and nematode infestation; these occurred for root length, number of tips, number of forks, root surface area, and number of fine roots (Table 2). There was a significant effect of seed treatment $(P=0.0005)$ on the numbers of $P$. penetrans extracted from soil. There was a significant main effect of seed treatment $(P=0.003)$ and also a significant interaction between seed treatment and fungal infestation $(P=0.01)$ affecting the numbers of nematodes extracted from the roots; treatments including the nematicide abamectin were the only ones differing significantly from the untreated control (Table 3). In $F$. verticillioides-infested treatments, there were significant main effects of seed treatment for all the variables except shoot length but treatment combinations rarely differed significantly from each other and, in many cases, only treatment 7 (FMA + thiabendazole + thiamethoxam + abamectin) differed from the untreated control (Table 5). In $P$. penetrans-inoculated treatments, there were fewer significant seed treatment effects (shoot length, shoot fresh weight, root length, number of forks, and length of fine roots) and the different treatment combinations rarely differed from each other (Table 5). Seed treatments did not affect any of the measured variables in the noninfested control treatments. $P$. penetrans was not detected in noninfested controls.

\section{Discussion}

Infestation of the potting medium with Fusarium spp. or P. penetrans had detrimental effects on most of the seedling health and root morphology variables measured in this study. Fungal infestation, particularly with $F$. graminearum, had a much larger effect than

Table 2. $P$ values for main and interactive effects of seed treatments and pathogen inoculation on seedling health variables for Fusarium graminearum and $F$. verticillioides experiments ${ }^{\mathrm{y}}$

\begin{tabular}{|c|c|c|c|c|c|c|c|c|}
\hline \multirow[b]{2}{*}{ Experiment } & \multirow[b]{2}{*}{ Variable } & \multicolumn{7}{|c|}{ Effects $^{\mathbf{z}}$} \\
\hline & & ST & $\mathbf{F}$ & $\mathbf{N}$ & $\mathbf{S T} \times \mathbf{F}$ & $\mathbf{S T} \times \mathbf{N}$ & $\mathbf{F} \times \mathbf{N}$ & $\mathbf{S T} \times \mathbf{F} \times \mathbf{N}$ \\
\hline \multirow[t]{11}{*}{ F. graminearum } & Shoot length $(\mathrm{cm})$ & ns & $<0.0001$ & ns & $<0.0001$ & 0.02 & ns & ns \\
\hline & Shoot fresh (g) & ns & $<0.0001$ & ns & $<0.0001$ & 0.01 & ns & ns \\
\hline & Shoot dry (g) & ns & $<0.0001$ & 0.003 & $<0.0001$ & ns & ns & ns \\
\hline & Root fresh (g) & ns & $<0.0001$ & ns & $<0.0001$ & 0.008 & ns & ns \\
\hline & Root dry $(\mathrm{g})$ & ns & $<0.0001$ & 0.004 & $<0.0001$ & ns & 0.009 & ns \\
\hline & Root length $(\mathrm{cm})$ & 0.0002 & $<0.0001$ & ns & 0.0009 & ns & ns & ns \\
\hline & Root volume $\left(\mathrm{cm}^{3}\right)$ & 0.01 & $<0.0001$ & ns & $<0.0001$ & ns & ns & ns \\
\hline & Tips & 0.001 & $<0.0001$ & ns & 0.01 & ns & ns & ns \\
\hline & Forks & 0.0003 & $<0.0001$ & ns & 0.001 & ns & ns & ns \\
\hline & Surface area $\left(\mathrm{cm}^{2}\right)$ & $<0.0001$ & $<0.0001$ & ns & $<0.0001$ & ns & ns & ns \\
\hline & Fine roots $(\mathrm{cm})$ & 0.002 & $<0.0001$ & ns & $<0.0001$ & ns & 0.04 & ns \\
\hline \multirow[t]{11}{*}{ F. verticillioides } & Shoot length $(\mathrm{cm})$ & ns & ns & ns & ns & 0.005 & ns & ns \\
\hline & Shoot fresh $(\mathrm{g})$ & ns & $\mathrm{ns}$ & ns & 0.009 & 0.004 & ns & ns \\
\hline & Shoot dry (g) & ns & ns & ns & ns & ns & ns & ns \\
\hline & Root fresh (g) & ns & $\mathrm{ns}$ & ns & 0.03 & ns & ns & ns \\
\hline & Root dry (g) & ns & ns & ns & ns & ns & ns & ns \\
\hline & Root length $(\mathrm{cm})$ & ns & $<0.0001$ & $<0.0001$ & 0.001 & 0.03 & 0.004 & ns \\
\hline & Root volume $\left(\mathrm{cm}^{3}\right)$ & ns & $<0.0001$ & 0.001 & 0.01 & $\mathrm{~ns}$ & ns & ns \\
\hline & Tips & ns & $<0.0001$ & $<0.0001$ & 0.004 & ns & 0.004 & ns \\
\hline & Forks & ns & $<0.0001$ & $<0.0001$ & 0.003 & 0.009 & 0.005 & ns \\
\hline & Surface area $\left(\mathrm{cm}^{2}\right)$ & ns & $<0.0001$ & $<0.0001$ & 0.001 & ns & 0.009 & ns \\
\hline & Fine roots $(\mathrm{cm})$ & ns & $<0.0001$ & $<0.0001$ & 0.001 & 0.04 & 0.001 & ns \\
\hline
\end{tabular}

y Analysis of variance was conducted with $\log _{10}$ transformed data except for disease root length (\%) and disease root volume (\%), which were not transformed. Separate experiments were conducted with $F$. graminearum and $F$. verticillioides. Data were combined for two runs of each experiment; ns $=$ not significant $(P>0.05)$.

${ }^{\mathrm{z}}$ Abbreviations: $\mathrm{ST}=$ seed treatment, $\mathrm{F}=$ fungus, and $\mathrm{N}=$ nematode. 
Table 3. Mean number of Pratylenchus penetrans recovered from $100 \mathrm{~cm}^{3}$ of soil and the maize roots therein and from $1 \mathrm{~g}$ (dry weight) of maize roots from treatments infested with the nematodes and with or without Fusarium spp. infestation ${ }^{\mathrm{y}}$

\begin{tabular}{|c|c|c|c|}
\hline $\begin{array}{l}\text { Experiment, } \\
\text { treatment }\end{array}$ & Active ingredients ${ }^{\mathrm{z}}$ & $\begin{array}{l}\text { Nematodes/100 } \\
\mathbf{c m}^{3} \text { of soil }\end{array}$ & $\begin{array}{c}\text { Nematodes/g } \\
\text { of root }\end{array}$ \\
\hline \multicolumn{4}{|c|}{$\begin{array}{l}\text { Fusarium } \\
\text { graminearum }\end{array}$} \\
\hline 1 & FMA & $57.5 \mathrm{~b}$ & $17.5 \mathrm{a}$ \\
\hline 2 & FMA + thiabendazole & $60.8 \mathrm{~b}$ & $13.3 \mathrm{a}$ \\
\hline 3 & FMA + thiamethoxam & $49.3 \mathrm{~b}$ & $12.0 \mathrm{a}$ \\
\hline 4 & $\begin{array}{l}\text { FMA + thiamethoxam } \\
+ \text { thiabendazole }\end{array}$ & $62.3 \mathrm{~b}$ & $10.0 \mathrm{ab}$ \\
\hline 5 & FMA + abamectin & $171.8 \mathrm{a}$ & $1.8 \mathrm{c}$ \\
\hline 6 & $\begin{array}{l}\text { FMA + abamectin + } \\
\text { thiabendazole }\end{array}$ & $156.5 \mathrm{a}$ & $0.0 \mathrm{c}$ \\
\hline 7 & $\begin{array}{l}\text { FMA + abamectin + } \\
\text { thiamethoxam }+ \\
\text { thiabendazole }\end{array}$ & $205.5 \mathrm{a}$ & $0.0 \mathrm{c}$ \\
\hline 8 & Untreated & $81.5 \mathrm{~b}$ & $9.5 \mathrm{ab}$ \\
\hline \multicolumn{4}{|c|}{ F. verticillioides } \\
\hline 1 & FMA & $47.7 \mathrm{c}$ & $10.0 \mathrm{abc}$ \\
\hline 2 & FMA + thiabendazole & $49.7 \mathrm{c}$ & $16.0 \mathrm{ab}$ \\
\hline 3 & FMA + thiamethoxam & $77.7 \mathrm{c}$ & $12.0 \mathrm{ab}$ \\
\hline 4 & $\begin{array}{l}\text { FMA + thiamethoxam } \\
+ \text { thiabendazole }\end{array}$ & $42.2 \mathrm{bc}$ & $18.7 \mathrm{a}$ \\
\hline 5 & FMA + abamectin & $148.7 \mathrm{a}$ & $0.0 \mathrm{c}$ \\
\hline 6 & $\begin{array}{l}\text { FMA + abamectin + } \\
\text { thiabendazole }\end{array}$ & $110.2 \mathrm{a}$ & $0.2 \mathrm{c}$ \\
\hline 7 & $\begin{array}{l}\text { FMA + abamectin + } \\
\text { thiamethoxam + } \\
\text { thiabendazole }\end{array}$ & $140.2 \mathrm{a}$ & $0.0 \mathrm{c}$ \\
\hline 8 & Untreated & $65.5 \mathrm{bc}$ & $7.5 \mathrm{bc}$ \\
\hline
\end{tabular}

$P$. penetrans infestation for most of the variables. There were large differences in root morphology between $F$. graminearum-infested treatments and $P$. penetrans-infested treatments; for example, overall root length was about $80 \%$ lower (Table 4 ) and fine root length was about $90 \%$ lower (data not shown) for $F$. graminearum-infested treatments. This reflects the severe effect of $F$. graminearum on root health; $P$. penetrans infestation alone, however, had a relatively small effect on root characteristics that we measured. There were significant interactions between $F$. graminearum and $P$. penetrans affecting root dry weight and the number of fine roots but the overwhelming effects of $F$. graminearum on the root variables may have detracted from the ability of the nematode to colonize roots and, therefore, limited the possibility of other interactions between the pathogens. In contrast, there were significant interactions between $F$. verticillioides and $P$. penetrans for several root health variables, and this may have occurred because $F$. verticillioides had a less drastic effect on the roots than $F$. graminearum.

There were several noticeable contrasts between the two Fusarium spp. regarding the effects of seed treatment, fungal infestation, nematode infestation, and fungus-nematode interactions (Table 2). For instance, there were greater effects of nematode infestation and fungus-nematode interactions in experiments with $F$. verticillioides than in experiments with $F$. graminearum. The $F$. verticillioides isolate used in the study was less aggressive than the $F$. graminearum isolate but displayed more evidence of significant interactions with $P$. penetrans for several variables. This observation suggests that the more aggressive $F$. graminearum isolate was better able to infect roots without the aid of the nematode but $F$. verticillioides was less effective without the aid of the nematode.

These results support previous research on synergistic interactions with $F$. verticillioides and plant-parasitic nematodes. Palmer and MacDonald (1974) and Palmer et al. (1967) reported a synergistic interaction between $P$. scribneri and $F$. verticillioides affecting fresh weight of maize seedlings in the presence of both pathogens. Moreover, Jordaan et al. (1987) reported that a combination of $P$. brachyurus and $P$. zeae can interact with the root-rot fungus $F$. moniliforme (syn. $F$. verticillioides) on maize, and this interaction

Table 4. Shoot and root measurements for maize seedlings grown from seed treated with different seed treatment products and grown in a sand/soil mixture infested with Fusarium graminearum inoculum or Pratylenchus penetrans adults and juveniles ${ }^{\mathrm{x}}$

\begin{tabular}{|c|c|c|c|c|c|c|c|}
\hline $\begin{array}{l}\text { Infestation, } \\
\text { treatmenty }\end{array}$ & Active ingredients ${ }^{\mathbf{z}}$ & $\begin{array}{l}\text { Shoot length } \\
\text { (cm) }\end{array}$ & $\begin{array}{c}\text { Shoot fresh } \\
\text { weight }(g)\end{array}$ & $\begin{array}{l}\text { Root length } \\
\text { (cm) }\end{array}$ & $\begin{array}{l}\text { Root fresh } \\
\text { weight (g) }\end{array}$ & $\begin{array}{l}\text { Root volume } \\
\left(\mathrm{cm}^{3}\right)\end{array}$ & $\underset{(n)}{\text { Root tips }}$ \\
\hline \multicolumn{8}{|c|}{ F. graminearum } \\
\hline 1 & FMA & $18.4 \mathrm{a}$ & $1.02 \mathrm{ab}$ & $40.9 \mathrm{~b}$ & $1.04 \mathrm{a}$ & $0.58 \mathrm{~b}$ & $68.5 \mathrm{ab}$ \\
\hline 2 & FMA + thiabendazole & $19.3 \mathrm{a}$ & $1.13 \mathrm{ab}$ & $44.8 \mathrm{ab}$ & $1.06 \mathrm{a}$ & $0.58 \mathrm{~b}$ & $64.6 \mathrm{bc}$ \\
\hline 3 & FMA + thiamethoxam & $17.1 \mathrm{a}$ & $0.95 \mathrm{~b}$ & $46.4 \mathrm{ab}$ & $0.98 \mathrm{a}$ & $0.67 \mathrm{ab}$ & $72.0 \mathrm{ab}$ \\
\hline 4 & $\begin{array}{l}\text { FMA + thiamethoxam + } \\
\text { thiabendazole }\end{array}$ & $19.1 \mathrm{a}$ & $0.94 \mathrm{~b}$ & $48.3 \mathrm{ab}$ & $0.93 \mathrm{a}$ & $0.62 \mathrm{~b}$ & $75.1 \mathrm{ab}$ \\
\hline 5 & FMA + abamectin & $19.5 \mathrm{a}$ & $0.96 \mathrm{ab}$ & $49.4 \mathrm{ab}$ & $0.91 \mathrm{a}$ & $0.68 \mathrm{ab}$ & $68.5 \mathrm{ab}$ \\
\hline 6 & FMA + abamectin + thiabendazole & $19.5 \mathrm{a}$ & $1.31 \mathrm{a}$ & $53.1 \mathrm{a}$ & $1.17 \mathrm{a}$ & $0.78 \mathrm{a}$ & $82.4 \mathrm{a}$ \\
\hline 7 & $\begin{array}{l}\text { FMA + abamectin + thiamethoxam } \\
+ \text { thiabendazole }\end{array}$ & $18.3 \mathrm{a}$ & $1.06 \mathrm{ab}$ & 52.9 a & $1.08 \mathrm{a}$ & $0.69 \mathrm{ab}$ & $79.1 \mathrm{ab}$ \\
\hline 8 & Untreated & $10.2 \mathrm{~b}$ & $0.35 \mathrm{c}$ & $28.2 \mathrm{c}$ & $0.33 \mathrm{~b}$ & $0.29 \mathrm{c}$ & $48.3 \mathrm{c}$ \\
\hline \multicolumn{8}{|l|}{ P. penetrans } \\
\hline 1 & FMA & $28.9 \mathrm{a}$ & $2.89 \mathrm{~b}$ & $168.9 \mathrm{~b}$ & $2.53 \mathrm{abc}$ & $1.18 \mathrm{~b}$ & $290 \mathrm{~b}$ \\
\hline 2 & FMA + thiabendazole & $27.4 \mathrm{bc}$ & $2.62 \mathrm{bc}$ & $186.1 \mathrm{ab}$ & $2.36 \mathrm{abc}$ & $1.39 \mathrm{~b}$ & $301 \mathrm{ab}$ \\
\hline 3 & FMA + thiamethoxam & $26.4 \mathrm{bc}$ & $2.63 \mathrm{bc}$ & $189.0 \mathrm{ab}$ & $2.38 \mathrm{bc}$ & $1.45 \mathrm{ab}$ & $301 \mathrm{ab}$ \\
\hline 4 & $\begin{array}{l}\text { FMA + thiamethoxam + } \\
\text { thiabendazole }\end{array}$ & $28.3 \mathrm{~b}$ & $2.61 \mathrm{bc}$ & $186.4 \mathrm{ab}$ & $2.44 \mathrm{bc}$ & $1.48 \mathrm{ab}$ & $314 \mathrm{ab}$ \\
\hline 5 & FMA + abamectin & $26.8 \mathrm{bc}$ & $2.72 \mathrm{bc}$ & $192.0 \mathrm{ab}$ & $2.10 \mathrm{~cd}$ & $1.51 \mathrm{ab}$ & $316 \mathrm{ab}$ \\
\hline 6 & FMA + abamectin + thiabendazole & $33.1 \mathrm{a}$ & $3.67 \mathrm{a}$ & $225.4 \mathrm{a}$ & $3.11 \mathrm{a}$ & $1.89 \mathrm{a}$ & $404 \mathrm{a}$ \\
\hline 7 & $\begin{array}{l}\text { FMA + abamectin + thiamethoxam } \\
+ \text { thiabendazole }\end{array}$ & $28.8 \mathrm{~b}$ & $2.89 \mathrm{~b}$ & $208.4 \mathrm{ab}$ & $2.81 \mathrm{ab}$ & $1.56 \mathrm{ab}$ & $329 \mathrm{ab}$ \\
\hline 8 & Untreated & $24.0 \mathrm{c}$ & $2.12 \mathrm{c}$ & $159.0 \mathrm{~b}$ & $1.76 \mathrm{~d}$ & $1.15 \mathrm{~b}$ & $262 \mathrm{~b}$ \\
\hline
\end{tabular}

x Values are means of two experiments with eight replications each. Values within a column and infestation treatment followed by the same letter are not significantly different according to Fisher's least significant difference $(\alpha=0.05)$.

${ }^{y} F$. graminearum-infested treatments include all those that were infested with $F$. graminearum (four replications with the fungus alone and four replications infested with both pathogens). $P$. penetrans-infested treatments include all those that were infested with $P$. penetrans (four replications with the nematode alone and four replications infested with both pathogens)

${ }^{2}$ FMA = fludioxonil + mefenoxam + azoxystrobin $=$ seed treatment 1 
can cause more severe effects on plant growth than the nematodes or fungus alone. A recent preliminary report by Lunt and MacGuidwin (2014) indicated that maize seedling growth did not differ significantly between single-pathogen and coinoculated treatments when $P$. penetrans was combined with $F$. verticillioides. This observation differs from the results reported here, potentially due to the different environmental and inoculum conditions between the two studies. Fusarium isolates within a species can display considerable variability (Desjardins 2006); therefore, it is not clear whether our results regarding differences between $F$. graminearum and $F$. verticillioides would be consistent across multiple isolates of each species.

In treatments infested with either or both pathogens, seed treatment combinations that included abamectin or abamectin with thiabendazole resulted in the healthiest and largest root systems compared with the untreated control or to a fungicide or insecticide seed treatment without abamectin. These results are consistent with previous work in cotton (Monfort et al. 2006), in which the authors reported increased plant height in abamectin-treated plants compared with control plants. Seed treatment effects were very prominent in the $F$. graminearum-infested treatments, where all seed treatment combinations resulted in significant improvements in all seedling variables compared with the untreated control. A likely explanation is the inclusion of fludioxonil, which is highly active against most isolates of F. graminearum (Munkvold and O'Mara 2002), in all the treatment combinations. Conditions in our growth chamber assay may have favored the demonstration of seed treatment efficacy because of the low soil volume, the soil mix that contained a high proportion of sand, and the use of high numbers of nematodes placed near the seed. Conversely, daily watering of the sand-soil mixture can leach away seed treatment active ingredients, and we did not observe abnormally high levels of $P$. penetrans infection in the untreated control, in spite of the high numbers added to each cone. Although the magnitude of seed treatment effects in this assay may not mimic those observed in the field, the assay provided an effective measure of the relative efficacy of the various treatments.

Population densities of $P$. penetrans from soil and roots were significantly affected by seed treatment. Seed treatment combinations with abamectin had lower population densities of $P$. penetrans in the roots but higher population densities in the soil compared with treatments without abamectin (Table 3). Apparently, seed treatment combinations containing abamectin protected the maize roots, reducing nematode penetration and altering the ratio of $P$. penetrans in the soil versus in the roots. Similarly, Cabrera et al. (2009), working with efficacy of abamectin seed treatment on $P$. zeae, found that penetration of $P$. zeae was reduced more than $80 \%$ in maize at a dose of $1.0 \mathrm{mg}$ a.i./seed. In the current study, $P$. penetrans population densities in roots also were significantly reduced by seed treatment combinations with abamectin, possibly resulting in higher numbers of nematodes recovered from soil. Abamectin is a broad-spectrum nematicide providing protection against a wide range of plant-parasitic nematode genera, including Belonolaimus, Criconemella, Helicotylenchus, Hoplolaimus, Longidorus, Meloidogyne, Pratylenchus, Trichodorus, Tylenchorhynchus, and Xiphinema (Lasota and Dybas 1990). However, abamectin used as a seed treatment nematicide provides early-season, not season-long, nematode protection, and the duration of protection is not specified or known. Thiabendazole has been reported to have some nematicidal activity against some species of nematode parasites that occurs in the upper digestive tract of various mammals (Kudo et al. 2008). There may be some evidence of such nematicidal activity in our study. For $P$. penetrans-infested treatments, only the seed treatment combination with both abamectin and thiabendazole was significantly different from the untreated control for several of the plant growth variables.

Emergence rate (data not shown) did not differ significantly among treatments, and all treatments were fully emerged at 20 days after planting. $P$. penetrans is not known to reduce emergence, and the temperature used in the experiments was not optimal for stand reduction by Fusarium spp. The temperature used in these experiments was within the optimal range for $P$. penetrans $\left(22\right.$ to $\left.25^{\circ} \mathrm{C}\right)$ (Castillo and Volvas 2007). Fusarium spp. can cause more severe symptoms in maize seed and seedlings when soil temperatures are below $13^{\circ} \mathrm{C}$ (Smith and White 1988), mainly because germination is greatly retarded in this temperature range. Therefore, in order to

Table 5. Shoot and root measurements for maize seedlings grown from seed treated with different seed treatment products and grown in a sand/soil mixture infested with Fusarium verticillioides inoculum or Pratylenchus penetrans adults and juveniles ${ }^{\mathrm{x}}$

\begin{tabular}{|c|c|c|c|c|c|c|c|}
\hline $\begin{array}{l}\text { Infestation, } \\
\text { treatmenty }\end{array}$ & Active ingredients ${ }^{\mathbf{z}}$ & $\begin{array}{l}\text { Shoot length } \\
\text { (cm) }\end{array}$ & $\begin{array}{c}\text { Shoot fresh } \\
\text { weight }(g)\end{array}$ & $\begin{array}{l}\text { Root length } \\
\text { (cm) }\end{array}$ & $\begin{array}{l}\text { Root fresh } \\
\text { weight (g) }\end{array}$ & $\begin{array}{l}\text { Root volume } \\
\left(\mathrm{cm}^{3}\right)\end{array}$ & $\underset{(n)}{\text { Root tips }}$ \\
\hline \multicolumn{8}{|c|}{ F. verticillioides } \\
\hline 1 & FMA & $26.6 \mathrm{a}$ & $2.28 \mathrm{ab}$ & $94.1 \mathrm{ab}$ & $1.49 \mathrm{ab}$ & $0.44 \mathrm{bc}$ & $188.1 \mathrm{ab}$ \\
\hline 2 & FMA + thiabendazole & $31.5 \mathrm{a}$ & $2.50 \mathrm{ab}$ & $101.2 \mathrm{ab}$ & $1.40 \mathrm{ab}$ & $0.49 \mathrm{bc}$ & $190.2 \mathrm{ab}$ \\
\hline 3 & FMA + thiamethoxam & $28.8 \mathrm{a}$ & $2.46 \mathrm{ab}$ & $98.5 \mathrm{ab}$ & $1.44 \mathrm{ab}$ & $0.48 \mathrm{bc}$ & $205.4 \mathrm{a}$ \\
\hline 4 & $\begin{array}{l}\text { FMA + thiamethoxam + } \\
\text { thiabendazole }\end{array}$ & $28.8 \mathrm{a}$ & $2.55 \mathrm{ab}$ & $113.1 \mathrm{ab}$ & $1.54 \mathrm{ab}$ & $0.56 \mathrm{ab}$ & $196.2 \mathrm{ab}$ \\
\hline 5 & FMA + abamectin & $34.0 \mathrm{a}$ & $2.54 \mathrm{ab}$ & $108.3 \mathrm{ab}$ & $1.43 \mathrm{ab}$ & $0.57 \mathrm{ab}$ & $208.7 \mathrm{a}$ \\
\hline 6 & FMA + abamectin + thiabendazole & $32.2 \mathrm{a}$ & $2.65 \mathrm{ab}$ & $130.4 \mathrm{a}$ & $1.62 \mathrm{ab}$ & $0.56 \mathrm{ab}$ & 249.9 a \\
\hline 7 & $\begin{array}{l}\text { FMA + abamectin + thiamethoxam } \\
+ \text { thiabendazole }\end{array}$ & $32.4 \mathrm{a}$ & $3.11 \mathrm{a}$ & 124.9 a & $1.78 \mathrm{a}$ & $0.65 \mathrm{a}$ & $255.3 \mathrm{a}$ \\
\hline 8 & Untreated & $26.4 \mathrm{a}$ & $1.99 \mathrm{~b}$ & $78.5 \mathrm{~b}$ & $1.24 \mathrm{~b}$ & $0.34 \mathrm{c}$ & $177.0 \mathrm{~b}$ \\
\hline \multicolumn{8}{|l|}{ P. penetrans } \\
\hline 1 & FMA & $23.7 \mathrm{ab}$ & $1.89 \mathrm{~b}$ & $181.8 \mathrm{ab}$ & $1.33 \mathrm{a}$ & $0.79 \mathrm{a}$ & $306 \mathrm{a}$ \\
\hline 2 & FMA + thiabendazole & $29.9 \mathrm{ab}$ & $2.56 \mathrm{ab}$ & $189.4 \mathrm{ab}$ & $1.52 \mathrm{a}$ & $0.84 \mathrm{a}$ & $306 \mathrm{a}$ \\
\hline 3 & FMA + thiamethoxam & $27.9 \mathrm{ab}$ & $2.47 \mathrm{ab}$ & $189.4 \mathrm{ab}$ & $1.49 \mathrm{a}$ & $0.81 \mathrm{a}$ & $315 \mathrm{a}$ \\
\hline 4 & $\begin{array}{l}\text { FMA + thiamethoxam + } \\
\text { thiabendazole }\end{array}$ & $30.7 \mathrm{ab}$ & $2.42 \mathrm{ab}$ & $185.6 \mathrm{ab}$ & $1.49 \mathrm{a}$ & $0.85 \mathrm{a}$ & 331 a \\
\hline 5 & FMA + abamectin & $29.9 \mathrm{ab}$ & $2.71 \mathrm{a}$ & $197.0 \mathrm{ab}$ & $1.69 \mathrm{a}$ & $0.91 \mathrm{a}$ & 379 a \\
\hline 6 & FMA + abamectin + thiabendazole & $30.1 \mathrm{ab}$ & $2.71 \mathrm{a}$ & $197.0 \mathrm{ab}$ & $1.53 \mathrm{a}$ & $0.91 \mathrm{a}$ & $347 \mathrm{a}$ \\
\hline 7 & $\begin{array}{l}\text { FMA + abamectin + thiamethoxam } \\
+ \text { thiabendazole }\end{array}$ & $32.2 \mathrm{a}$ & $2.71 \mathrm{a}$ & $212.1 \mathrm{a}$ & $1.66 \mathrm{a}$ & $0.90 \mathrm{a}$ & 379 a \\
\hline 8 & Untreated & $19.2 \mathrm{~b}$ & $1.84 \mathrm{~b}$ & $168.9 \mathrm{~b}$ & $1.31 \mathrm{a}$ & $0.71 \mathrm{a}$ & $290 \mathrm{a}$ \\
\hline
\end{tabular}

$x$ Values are means of two experiments with eight replications each. Values within a column and infestation treatment followed by the same letter are not significantly different according to Fisher's least significant difference $(\alpha=0.05)$.

${ }^{y} F$. verticillioides-infested treatments include all those that were infested with $F$. verticillioides (four replications with the fungus alone and four replications infested with both pathogens). P. penetrans-infested treatments include all those that were infested with $P$. penetrans (four replications with the nematode alone and four replications infested with both pathogens).

${ }^{\mathrm{z}} \mathrm{FMA}=$ fludioxonil + mefenoxam + azoxystrobin $=$ seed treatment 1. 
fully understand $P$. penetrans interactions with seedling pathogens, these studies should be repeated under a range of temperatures.

Image analysis of root structure analysis using WinRhizo showed that seed treatments significantly improved root system characteristics such as root volume, root length, number of tips, forks, surface area, and fine root development. Some variables calculated by the software were highly correlated and, in this study, demonstrated very similar treatment effects (e.g., root volume and surface area, and root tips and forks). Fine root length (data not shown) was highly correlated with total root length and, in nearly all cases, seed treatments increased fine root length compared with the control; however, there were few differences among treatments for this variable. Image analysis facilitated more precise quantification of root health and morphology variables in order to measure pathogen and seed treatment effects on roots. WinRhizo has been reported to provide accurate measurements of root morphological parameters (Himmelbauer et al. 2004). Root morphological characteristics measured in this study, including length and surface area, are important indicators for potential uptake of water and nutrients (Himmelbauer et al. 2004; Pallant et al. 1993; Zobel et al. 2007). Root image analysis data indicated similar effects of fungal and nematode infestation but effects were more dramatic with $F$. graminearum than with $F$. verticillioides. Furthermore, there were significant seed treatment interactions with both fungal and nematode infestation, reducing root rot and enhancing root system characteristics in infested treatments. There were no significant three-way interactions, suggesting that seed treatment did not alter the nature of the Fusarium-Pratylenchus interaction.

The seed treatments in this study had no effect on the plant growth variables in treatment combinations that were not infested with Fusarium spp. or $P$. penetrans in these experiments. The absence of such effects indicates that seed treatment effects on maize seedlings were due to suppression of pathogen activity, and not direct effects on plant physiology. Although thiamethoxam seed treatment has been associated with direct physiological effects on plants (Perelló and Dal Bello 2011), we did not see evidence for that in this study; treatment 7 (with thiamethoxam) rarely differed from treatment 6 (the same combination without thiamethoxam). There were no negative effects concerning phytotoxicity, such as lower germination, stunting, or chlorosis.

To our knowledge, this study is the first to assess the interactions between $P$. penetrans and Fusarium spp. on maize roots in relation to the potential benefits of abamectin combined with fungicidal seed treatment. Data obtained in this study provide evidence that abamectin in combination with fungicidal seed treatments significantly improved the protection of the maize root system against $P$. penetrans infection and seedling disease symptoms. In addition, our research presents novel data regarding root system characteristics in response to fungal and nematode infestation and seed treatments, as measured by root image analysis.

The results demonstrated significant effects of seed treatments on root health with interactions between fungal pathogens and $P$. penetrans. Seed treatments showed efficacy against fungal and nematode infestations, improving most measures of seedling health compared with the untreated control, particularly seed treatment combinations that included abamectin and thiabendazole. Root structure analysis using WinRhizo was a powerful tool to demonstrate benefits of seed treatment toward improved root system characteristics such as root volume, root length, number of tips, forks, surface area, and fine roots.

\section{Acknowledgments}

This research was supported by Syngenta Crop Protection, Basel, Switzerland. We thank A. MacGuidwin, University of Wisconsin, Madison, for providing $P$. penetrans cultures and for assistance with nematode culture methods.

\section{Literature Cited}

Atkinson, G. F. 1892. Some diseases of cotton. Ala. Polytech. Inst. Agric. Exp. Stn. Bull. No. 41:61-65.

Back, M. A., Haydock, P. P. J., and Jenkinson, P. 2002. Disease complexes involving plant parasitic nematodes and soilborne pathogens. Plant Pathol. 51:683-697.

Burpee, L. L., and Bloom, J. R. 1978. The influence of Pratylenchus penetrans on the incidence and severity of Verticillium wilt of potato. Nematology 10:95-99.
Cabrera, J. A., Kiewnick, S., Grimm, C., Dababat, A. A., and Sikora, R. A. 2009. Efficacy of abamectin seed treatment on Pratylenchus zeae, Meloidogyne incognita and Heterodera schachtii. J. Plant Dis. Prot. 116:124-128.

Castillo, P., and Volvas, N. 2007. Pratylenchus (Nematoda: Pratylenchidae) Diagnosis, Biology, Pathogenicity, and Management. Nematology Monographs and Perspectives, Vol. 6. Koninklijke Brill NV, Leiden, The Netherlands.

Corbett, D. C. M. 1973. Pratylenchus penetrans. C.I.H. Descriptions of Plant Parasitic Nematodes, Set 2, No. 25. Commonwealth Institute of Helminthology, Commonwealth Agriculture Bureaux, Albans, Herts., England.

Desjardins, A. E. 2006. Fusarium Mycotoxins, Chemistry, Genetics, and Biology. American Phytopathological Society, St. Paul, MN.

Desjardins, A. E., Plattner, R. D., Nelson, T. C., and Leslie, J. F. 1995. Genetic analysis of fumonisin production and virulence of Gibberella fujikuroi, mating population A (Fusarium moniliforme) on maize (Zea mays) seedlings. Appl. Environ. Microbiol. 61:79-86.

De Waele, D., and Elsen, A. 2002. Migratory endoparasites: Pratylenchus and Radopholus species. Pages 185 to 216 in: Plant Resistance to Parasitic Nematodes. J. L. Starr, R. Cook, and J. Bridges, eds. CABI Publishing, Wallingford, Oxon, UK.

Endo, B. Y. 1975. Pathogenesis of nematode-infected plants. Annu. Rev Phytopathol. 13:213-238.

Gamborg, O. L., Murashige, T., Thorpe, T. A., and Vasil, I. K. 1976. Plant tissue culture media. In Vitro 12:473-478.

Himmelbauer, M. L., Loiskandl, W., and Kastanek, F. 2004. Estimating length, average diameter and surface area of fine roots using two different image analyses systems. Plant Soil 260:111-120.

Huan, J., Santo, G. S., and Mojtahedi, H. 1988. Effect of Pratylenchus pentrans, Erwinia carotovora subsp. carotovora and Verticilillium dahliae on potato yield in microplots. Nematology 20:640-641.

Jenkins, W. R. 1964. A rapid centrifugal-flotation technique for extracting nematodes from soil. Plant Dis. Rep. 48:692.

Jordaan, E. M., Loots, G. C., Jooste, W. J., and De Waele, D. 1987. Effects of rootlesion nematodes (Pratylenchus branchyurus Godfrey and P. zeae Graham) and Fusarium moniliforme Sheldon alone or in combination, on maize. Nematologica 33:213-219.

Kudo, N., Kubota, H., Gotoh, H., Ishida, H., Ikadai, H., and Oyamada, T. 2008 Efficacy of thiabendazole, mebendazole, levamisole and ivermectin against gullet worm, Gongylonema pulchrum: In vitro and in vivo studies. Vet. Parasitol. 151:46-52.

Lasota, J. A., and Dybas, R. A. 1990. Abamectin as a pesticide for agricultural use. Acta Leiden. 59:217-225.

Layne, T. L., and MacGuidwin, A. E. 1994. Recovery of Pratylenchus penetrans from plant tissue cultures. (Abstr.) Nematology 26:557.

Leslie, J. F., and Summerell, B. A., eds. 2006. The Fusarium Laboratory Manual. Blackwell Publishing, Ames, IA.

Loof, P. A. A. 1991. The family Pratylenchidae. Pages 363-421 in: Manual of Agricultural Nematology. W. R. Nickle, ed. Marcel Dekker, Inc., New York.

Lunt, T., and MacGuidwin, A. 2014. Interaction studies of Pratylenchus penetrans and Fusarium verticillioides on corn seedlings. (Abstr.) Phytopathology 104: S3.73.

Mai, W. F., Bloom, J. R., and Chen, T. A. 1977. Biology and ecology of the plantparasitic nematode Pratylenchus penetrans. Penn. State Univ. Agric. Exp. Stn. Bull. No. 815.

Martin, M. J., Riedel, R. M., and Rowe, R. C. 1982. Verticillium dahliae and Pratylenchus penetrans: Interactions in the early dying complex of potato in Ohio. Phytopathology 72:640-644.

McKenry, M., Buzo, T., Kretsch, J., Kaku, S., Otomo, E., Ashcroft, R., Lange, A., and Kelley, K. 1994. Soil fumigants provide multiple benefits: Alternatives give mixed results. Calif. Agric. 48:22-28. Online publication. http://ucanr.edu/ repositoryfiles/ca4803p22-70118.pdf

Monfort, W. S., Kirkpatrick, T. L., Long, D. L., and Rideout, S. 2006. Efficacy of a novel nematicidal seed treatment against Meloidogyne incognita on cotton. J. Nematol. 38:245-249.

Mountain, W. B., and McKeen, C. D. 1962. Effect of Verticillium dahliae on the population of Pratylenchus penetrans. Nematologica 7:261-266.

Munkvold, G. P., and O'Mara, J. K. 2002. Laboratory and growth chamber evaluation of fungicidal seed treatments for maize seedling blight caused by Fusarium species. Plant Dis. 86:143-150.

Newson, L. D., and Martin, W. J. 1953. Effects of soil fumigation on populations of plant parasitic nematodes, incidence of Fusarium wilt and yield of cotton. Phytopathology 43:292-293.

Norton, D. C. 1984. Nematode parasites of corn. Pages 61-94 in: Plant and Insect Nematodes. W. R. Nickle, ed. M. Dekker, New York.

Norton, D. C., and Hinz, P. N. 1976. Relationship of Hoplolaimus galeatus and Pratylenchus hexincisus to reduction of corn yields in sandy soils in Iowa Plant Dis. Rep. 60:197-200.

Olthof, T. H. A., and Reynes, A. A. 1969. Effect of Pratylenchus penetrans on Verticillium wilt of pepper. (Abstr.) Nematology 1:21-22.

Pallant, E., Holmgren, R. A., Schuler, G. E., McCracker, K. L., and Drbal, B. 1993. Using a fine root extraction device to quantify small diameter corn roots $(>0.025 \mathrm{~mm})$ in field soils. Plant Soil 153:273-279. 
Palmer, L. T., and MacDonald, D. H. 1974. Interactions of Fusarium spp. and certain plant parasitic nematodes on maize. Phytopathology 64:14-17.

Palmer, L. T., MacDonald, D. H., and Kommedahl, T. 1967. The ecological relationship of Fusarium moniliforme to Pratylenchus scribneri in seed blight on corn. (Abstr.) Phytopathology 57:825.

Perelló, A. E., and Dal Bello, G. M. 2011. Suppression of tan spot and plant growth promotion of wheat by synthetic and biological inducers under field conditions. Ann. Appl. Biol. 158:267-274.

Potter, J. W., and Townshend, J. L. 1973. Distribution of plant-parasitic nematodes in field crop soils of Southern and Central Ontario. Plant Dis. 53:39-48.

Robertson, A., and Munkvold, G. P. 2009. Check general root and mesocotyl health when assessing corn stands. Iowa State University Integrated Crop Management Newsletter. Online publication. http://www.extension.iastate. edu/CropNews/2009/0519robertson.htm

Rowe, R. C., and Powelson, M. L. 2002. Potato early dying: Management challenges in a changing production environment. Plant Dis. 86: 1184-1193.

Rowe, R. C., Riedel, R. M., and Martin, M. J. 1985. Synergistic interactions between Verticillium dahliae and Pratylenchus penetrans in potato early dying disease. Phytopathology 75:412-418.
Saeed, I. A. M., MacGuidwin, A. E., and Rouse, D. I. 1999. Limitation to photosynthesis in Pratylenchus penetrans- and Verticillium dahliae-infected potato. Crop Sci. 39:1340-1346.

Smith, A. L. 1948. Control of cotton wilt and nematodes with a soil fumigant. Phytopathology 38:934-947.

Smith, D. R., and White, D. G. 1988. Diseases of corn. Pages 687-766 in: Corn and Corn Improvement, 3rd ed. Agron. Ser. No. 18. G. F. Sprague and J. W. Dudley, eds. American Society of Agronomy, Madison, WI.

Stack, J. 2000. Management of seed and seedling diseases of corn. University of Nebraska-Lincoln Extension NF00-427. Online publication. http://digitalcommons unl.edu/cgi/viewcontent.cgi?article $=1889 \&$ context=extensionhist

United Nations Environment Programme. 1992. Synthesis report of the methyl bromide interim scientific assessment and methyl bromide interim technology and economic assessment. Montreal Protocol Assessment Supplement, Nairobi, Kenya.

Vincelli, P. 2008. Seed and seedling diseases of corn. UK Coop. Ext. Serv. Univ. Ky. Coll. Agric. Plant Pathol. Fact Sheet PPFS-AG-C-02. Online publication. http:// www2.ca.uky.edu/agcollege/plantpathology/ext_files/PPFShtml/PPFS-AG-C-2.pdf

Zobel, R. W., Kinraide, T. B., and Baligar, V. C. 2007. Fine root diameters can change in response in nutrient concentration. Plant Soil 297:243-254. 